\title{
YOUTH LABOR FORCE PARTICIPATION IN THAI NGUYEN PROVINCE, VIETNAM
}

Bui Van Luong', Phuong Huu Khiem ${ }^{2 *}$, Do Anh Tai ${ }^{3}$

${ }^{I}$ The Committee of Pho Yen town, Thai Nguyen province,

${ }^{2} \mathrm{TNU}$ - International School, ${ }^{3} \mathrm{TNU}$ - University of Economics, Business and Administration

\begin{tabular}{|c|c|c|}
\hline \multicolumn{2}{|c|}{ ARTICLE INFO } & ABSTRACT \\
\hline Received: & $14 / 4 / 2021$ & In many countries, the youth labour force was determined as a main \\
\hline Revised: & $14 / 5 / 2021$ & $\begin{array}{l}\text { engine in human capital development. This research was conducted to } \\
\text { identify the factors that affected the youth labour force participation in }\end{array}$ \\
\hline Published: & $19 / 5 / 2021$ & Thai Nguyen province, Vietnam by using the database from the \\
\hline & & National Labour Force Survey in 2014, 2015 and 2016, with \\
\hline \multicolumn{2}{|l|}{ KEYWORDS } & the employment of the probit model. Our findings indicated that many \\
\hline \multicolumn{2}{|l|}{ Youth } & statistical significant level, including individual characteristics (age, \\
\hline \multicolumn{2}{|l|}{ Labour force } & gender, living location, educational level) and household demographic \\
\hline \multicolumn{2}{|l|}{ Employment } & feature (household size). Interestingly, the results showed that there was \\
\hline \multicolumn{2}{|l|}{ Probit model } & hereby young \\
\hline \multirow{2}{*}{\multicolumn{2}{|c|}{ Thai Nguyen province }} & $\begin{array}{l}\text { Were less likely to participate in the labour market than young men } \\
(0.66 \% \text { points }) \text { while young people living in rural areas were more }\end{array}$ \\
\hline & & $\begin{array}{l}\text { likely to join the labour force than young people living in urban areas } \\
\text { (about } 1.42 \% \text { points). }\end{array}$ \\
\hline
\end{tabular}

\section{SỰ THAM GIA LỰC LƯợNG LAO ĐỘNG CỦA THANH NIÊN TẶI TỈNH THÁI NGUYỂ, VIẸT NAM}

\author{
Bùi Văn Lương ${ }^{1}$, Phương Hữu Khiêm ${ }^{2 *}$, Đỗ Anh Tài ${ }^{3}$ \\ ${ }^{1}$ Ủy ban nhân dân thị xã Phổ Yên, tỉnh Thái Nguyên \\ ${ }^{2}$ Khoa Quốc tế - ĐH Thái Nguyên \\ ${ }^{3}$ Truò̀ng Đại học Kinh tế và Quản trị kinh doanh - ĐH Thái Nguyên
}

\begin{tabular}{|c|c|c|}
\hline \multicolumn{2}{|c|}{ THÔNG TIN BÀI BÁO } & TÓM TẮT \\
\hline Ngày nhận bài: & $14 / 4 / 2021$ & Ở nhiều quốc gia, lực lượng lao động thanh niên luôn được xác định là \\
\hline Ngày $h$ & $14 / 5 / 20$ & $\begin{array}{l}\text { động lực chính trong phát triến vốn con người. Nghiên cứu này được } \\
\text { thực hiện nhắm xác định các yếu tố ảnh hưởng đến việc tham gia lực }\end{array}$ \\
\hline Ngày đăng: & $19 / 5 / 2021$ & $\begin{array}{l}\text { lượng lao động thanh niên ở tỉnh Thái Nguyên, Việt Nam bằng cách sử } \\
\text { dụng cơ sở dữ liệu từ Điều tra Quốc gia về Lực lượng Lao động Việt }\end{array}$ \\
\hline \multicolumn{2}{|l|}{ TÙ KHÓA } & Nam năm 2014, 2015 và 2016, phân tích sử dụng mô hình probit. Kết \\
\hline \multicolumn{2}{|l|}{ Thanh niên } & lượng lao động của thanh niên có mức ý nghĩa thống kê cao, bao gồm \\
\hline \multicolumn{2}{|l|}{ Lực lượng lao động } & đặc điểm cá nhân (tuổi, giới tính, vị trí sinh sống, trình độ học vấn) và \\
\hline \multicolumn{2}{|l|}{ Việc làm } & a khẩu học của hộ gia đình (quy mô hộ gia đình). Điều \\
\hline \multicolumn{2}{|l|}{ Mô hình probit } & $\begin{array}{l}\text { đáng quan tâm là kêt quá cho thây có sự chênh lệch giữa các nhóm giới } \\
\text { và khu vực sống, thanh niên nữ ít có khả năng tham gia vào thị trường }\end{array}$ \\
\hline \multicolumn{2}{|l|}{ Tỉnh Thái Nguyên } & $\begin{array}{l}\text { lao động hơn so với nam thanh niên }(0,66 \% \text { điểm). Trong khi thanh } \\
\text { niên sông ở nông thôn có xác suất tham gia lực lượng lao động cao hơn } \\
\text { so với thanh niên sống ở thành thị (khoảng } 1,42 \% \text { điểm). }\end{array}$ \\
\hline
\end{tabular}

DOI: $\underline{\text { https://doi.org/10.34238/tnu-jst.4348 }}$

*Corresponding author. Email: phuonghuukhiem@tnu.edu.vn

http://jst.tnu.edu.vn 3 Email: jst@tnu.edu.vn




\section{Introduction}

Vietnam has achieved many successes in term of economic development and marked a nation economy from one of the poorest countries in the world to become a low-middle income country with GDP growth remaining at around $10 \%$ for the last decades. The poverty rate has declined sharply from 58\% in 1993 to $14.5 \%$ in 2008, and then approximately $9.8 \%$ in 2016 [1]. Thank to these achievements, the Vietnamese Central Government always determines human capital accumulation as a crucial factor in the national development in which the youth labour force has played an important role contributing to the national economic growth. Therefore, understanding the youth behaviour or identifying the factors that can impact on the youth decision about participating in the labour market is necessary. However, so far there are limited studies that deal with this issue in Vietnam in general, and at the province level in particular.

Long and Ly studied the factors affecting on labour force participation of older people in Vietnam, they employed data from the Vietnam Aging Survey in 2011 and used the probit model in measurement and analysis. Their findings show that various individual factors (such as age and health status) and household-related factors (such as area of living) significantly contributed to older people's decision on participating in the labour force. More interestingly, the effects of the above factors were statistically and significantly different for males and females and those living in urban and rural areas [2]. Kreibaum and Klasen investigated the effect of the Vietnam War and the socialist regime in the Northern part of the country on female labour force participation. By using the probit model in estimation, their results show that the effect of 'missing men' on the work status of women was found to be positive and significant for the cohorts directly affected by the war [3].

Mendolia et al. [4] studied the impact of parental illness on children (aged between 11 and 23) labour force participation in Vietnam. Their findings indicated that the factors of child characteristics (age, living areas, ethnicity, gender, educational level, marital status) and household demographic feature (household size or number of children) had an impact on children choice to enter to the labour market in Vietnam. Tuyen et al. [5] examined for the first time the effect of individual and family characteristics, firm agglomeration, and the quality of labour training (provided by provincial governments) on occupational choice among young people in Vietnam. They found that females were more likely than males to have better jobs, even after controlling for all other variables in the models. Higher levels of education were the most important factor in choosing non-manual jobs, while family background (as measured by father's occupation) played a significant role in explaining young people's occupational choice.

Tuyet [6] conducted a research in youth transition to employment in Vietnam, and the findings illustrated that Vietnamese youth had to face many challenges when negotiating their transition to work, especially when the educational attainment of the majority youth was low. Liu et al. [7] provided a detailed description of rural labour market evolution and how it relates to the structural transformation of rural Vietnam, especially within the agricultural sector. Their results show the limited employment creation potential of agriculture, especially for youth. Moreover, the study of Klasen et al. [8] determined the factors affecting on labour force participation of urban married women in eight low- and middle-income economies: Bolivia, Brazil, India, Indonesia, Jordan, South Africa, Tanzania, and Vietnam. They found that the returns to the characteristics of women and their families differed substantially across countries and the economic, social, and institutional constraints that shape women's labour force participation remained largely country-specific.

Located in the Northeast region of Vietnam, Thai Nguyen province is roughly $70 \mathrm{kms}$ from Ha Noi capital and is considered the centre of the Northeast region. According to the General Statistics Office [9], Thai Nguyen has a population of approximately 1.3 million people. For recent years, Thai Nguyen has emerged as one of the most dynamic provinces in Vietnam in 
attracting FDI investment. For instance, the Samsung Group has invested and opened one of the biggest factory in digital production over the world since 2014. In addition, Thai Nguyen province is also home to Thai Nguyen University, which ranks the number third in terms of scale with multi-disciplinary training in Vietnam. Thus, in this paper, we choose Thai Nguyen province - a province of good labour market for young workers, for our research area and as a case study in Vietnam.

\section{Research data and empirical method}

\subsection{Research data}

In this paper, we employed the database from the Vietnam National Labour Force Survey (LFS) from the years of 2014, 2015 and 2016; then, the data was filtered for the Thai Nguyen province level. LFS was designed and conducted by Vietnam General Statistics Office with the finance and technique supported by International Labour Organization (ILO), due to the advantages in this database as compared to other databases in Vietnam. This database has a large sample size and multiple information for individual or household level. In this research, we selected the sample size based on the Vietnam Law of Youth in 2005, accordingly, in Article 1, they defined that "Young people referred to in this law are Vietnamese citizens aged between sixteen and thirty years" [10]. The authors chose the target youth as people in the age range of 16-30. Based on literature reviews, the selected variables included in an econometric model (Table 1). Namely, the selection of these variables resembles the literature of personal-level determinants relating to labor force participation used by Long et al. [2] and $\mathrm{Xu}$ et al. [11].

Table 1. Definition of variables used in this study

\begin{tabular}{|c|c|c|}
\hline Variable codes & Type & Definition \\
\hline \multicolumn{3}{|l|}{ Dependent variable } \\
\hline $\boldsymbol{L F P}$ & $\mathrm{D}$ & Youth labor force participation \\
\hline \multicolumn{3}{|l|}{ Independent variables } \\
\hline$A G E$ & $\mathrm{C}$ & Age of youth, as of higher last birthday \\
\hline$A G E \_S Q$ & $\mathrm{C}$ & Age square of youth \\
\hline $\operatorname{RUR} \bar{A} L$ & $\mathrm{D}$ & Living in rural area \\
\hline FEMALE & $\mathrm{D}$ & Youth is female \\
\hline MARRIED & $\mathrm{D}$ & Current married \\
\hline Education levels & & $\begin{array}{l}\text { The highest grade of education (including official and non-official } \\
\text { education) that youth has finished or graduated }\end{array}$ \\
\hline NO-EDUC & $\mathrm{D}$ & Never attended school or not graduated primary school yet \\
\hline PRIMARY & $\mathrm{D}$ & Graduated Primary school \\
\hline SECONDARY & $\mathrm{D}$ & Graduated Secondary school \\
\hline HIGH_SCHOOL & $\mathrm{D}$ & Graduated High school \\
\hline COLLEGE_OVER & $\mathrm{D}$ & Graduated college and over school \\
\hline HSIZE & $\mathrm{D}$ & Total number of family members (person) \\
\hline TIME & $\mathrm{D}$ & $\begin{array}{l}\text { Time trend, as the number of years from the start of the study } \\
\text { period, time }=1,2,3\end{array}$ \\
\hline
\end{tabular}

Source: own specification; Note: $D=$ discontinuous variables; $C=$ Continuous variables.

Table 2 shows the detail in the sample size and the list of variables used in this paper. It indicates that the number of young people living in rural area exceeded the quantities of urban people while around 50 per cent of young people got married. Moreover, in the educational aspect, the people receiving no education and primary school level accounted for a small scale, most of whom have already finished the secondary school and high school level. 
Table 2. Descriptive statistics

\begin{tabular}{|c|c|c|c|c|}
\hline & Means & Std. Dev. & Min & Max \\
\hline \multicolumn{5}{|l|}{ Dependent variable } \\
\hline$L F P$ & 0.720 & 0.448 & 0 & 1 \\
\hline \multicolumn{5}{|c|}{ Independent variables } \\
\hline$A G E$ & 23.534 & 4.297 & 16 & 30 \\
\hline$A G E \_S Q$ & 572.334 & 200.295 & 256 & 900 \\
\hline $\operatorname{RURA} \boldsymbol{L}$ & 0.580 & 0.493 & 0 & 1 \\
\hline FEMALE & 0.504 & 0.500 & 0 & 1 \\
\hline MARRIED & 0.463 & 0.498 & 0 & 1 \\
\hline \multicolumn{5}{|l|}{ Education levels } \\
\hline NO-EDUC & 0.015 & 0.123 & 0 & 1 \\
\hline PRIMARY & 0.074 & 0.262 & 0 & 1 \\
\hline SECONDARY & 0.330 & 0.470 & 0 & 1 \\
\hline HIGH_SCHOOL & 0.391 & 0.488 & 0 & 1 \\
\hline COLLEGE_OVER & 0.187 & 0.390 & 0 & 1 \\
\hline HSIZE & 4.498 & 1.788 & 1 & 19 \\
\hline TIME & 1.957 & 0.820 & 1 & 3 \\
\hline Observations & 7,806 & & & \\
\hline
\end{tabular}

\subsection{Empirical method}

To determine the factors that may influence the youth decision to participate in the labour force, a research methodology similar to Long et al. [2] and $\mathrm{Xu}$ et al. [11] was followed. In this paper, we used the probit model setup in analysis with a probit model as follows:

$$
\begin{aligned}
& P\left(Y_{i t}=1\right)=\Phi\left(\beta_{0}+\beta_{1} A G E_{i t}+\beta_{2} A G E_{-} S Q_{i t}+\beta_{3} R U R A L_{i t}+\beta_{4} \text { FEMALE }_{i t}\right. \\
& \left.+\beta_{5} \text { MARRIED }_{i t}+\beta_{6} E_{\text {EDU }}+\beta_{7} \text { HSIZE }_{i t}+\beta_{8} T I M E_{i t}+U_{i t}\right)
\end{aligned}
$$

where $Y_{i t}=$ youth labour force participation is a dummy variable. The explanatory variables used in this model include a vector of the characteristics of the youth (age, age square are depicted for the youth experience, age is measured as a continuous variable; rural is a dummy variable, rural equals 1 and 0 otherwise; female also is a dummy variable indicating the difference between gender groups, it equals 1 , female and 0 , otherwise; married illustrates to the marital status, it equals 1 indicating the current married and 0 otherwise; education is the firstconsidered human capital variable and young people are divided into five subgroups, one for those who have not finished primary school; the second group involves those who have completed lower secondary school, the third has obtained the secondary level, the fourth has finished the high school level and the last implies those who have got the college and higher degrees). In addition, the household size variable shows the demographic feature for each family, and the time-variable is a proxy variable for the time trend over years $(\mathrm{t}=$ number of years from the start of the study period, $\mathrm{t}=1,2,3$ respectively with year $=2014,2015,2016$ ).

\section{Empirical results}

\subsection{Young labour force participation rate by characteristics}

To identify the factors that may impact the youth LFP choice, we run several probit regressions, beginning with the total sample size combined with the youth characteristics, and some sub-groups for each year. Then, we wanted to find the difference among the other subsample size with location, gender and aged groups. In this paper, to bring convenience for the reader, all the probit estimations were transferred to marginal effect.

Table 3 shows the estimated results for four sample sizes (total sample size and for three subsamples with three years respectively). The various test of goodness-of-fit indicated that the 
selected covariates provided good estimates to use model. For example, LR chi2(11) test statistics indicated that explanatory variables were jointly statistically significant $(\mathrm{p}<0.01)$. The results revealed that all the independent variables used in this paper had an impact on the LFP rate of the youth in Thai Nguyen province with a high statistical significant level. The results were consistent with all four models. While age, rural, current married, and household size variables had positive impacts on the youth choice in LFP, the variables of female, lower level of education and time variables had negative impacts on the LFP of the youth.

Namely, age had a strong positive impact on youth labor force participation (around 2\% point in four models). Married youth was more likely to join the labour market than that with youth in counterpart group. In addition, in term of education level group, youth with no education level had a lower probability to participate the labour market in comparison with people in counterpart group. It can be explained that the labour market has required workers with education or skill workers recently. In contrast, people owning the high school degree were less likely to go to work than people who did not own the high school level. It can be interpreted that they had a higher probability to continue to study at the college or universities. Time variable had a negative influence on youth LFP (roughly $1.32 \%$ points), which is suitable in this period in Vietnam, when the living standard was improved, it could create more studying opportunities for youth so they delay to go to work in recent years.

Table 3. Probit LFP rate by characteristics and years

\begin{tabular}{|c|c|c|c|c|}
\hline & $\begin{array}{c}\text { Total sample size } \\
\text { (1) }\end{array}$ & $\begin{array}{l}2014 \\
(2)\end{array}$ & $\begin{array}{c}2015 \\
(3)\end{array}$ & $\begin{array}{l}2016 \\
(4)\end{array}$ \\
\hline \multirow[t]{2}{*}{$A G E$} & $0.206 * * *$ & $0.181 * * *$ & $0.177 * * *$ & $0.241 * * *$ \\
\hline & $(0.016)$ & $(.025)$ & $(0.028)$ & $(0.033)$ \\
\hline \multirow[t]{2}{*}{$A G E \_S Q$} & $-0.003 * * *$ & $-0.003 * * *$ & $-0.002 * * *$ & $-0.004 * * *$ \\
\hline & $(0.000)$ & $(0.000)$ & $(0.000)$ & $(0.000)$ \\
\hline \multirow[t]{2}{*}{$R U R A L$} & $0.143 * * *$ & $0.105 * * *$ & $0.172 * * *$ & $0.159 * * *$ \\
\hline & $(0.010)$ & $(0.014)$ & $(0.020)$ & $(0.022)$ \\
\hline \multirow[t]{2}{*}{ FEMALE } & $-0.095 * * *$ & $-0.073 * * *$ & $-0.103 * * *$ & $-0.108 * * *$ \\
\hline & $(0.010)$ & $(0.014)$ & $(0.017)$ & $(0.019)$ \\
\hline \multirow[t]{2}{*}{ MARRIED } & $0.162 * * *$ & $0.172 * * *$ & $0.126 * * *$ & $0.176^{* * *}$ \\
\hline & $(0.012)$ & $(0.017)$ & $(0.023)$ & $(0.024)$ \\
\hline \multirow{2}{*}{$N O-E D U C$} & $-1.37 * * *$ & $-0.500 * * *$ & $-0.520 * * *$ & $-0.419 * * *$ \\
\hline & $(0.150)$ & $(0.082)$ & $(0.113)$ & $(0.113)$ \\
\hline \multirow{2}{*}{ PRIMARY } & $0.437 * *$ & $0.108 * * *$ & 0.048 & 0.082 \\
\hline & $(0.016)$ & $(0.020)$ & $(0.058)$ & $(0.058)$ \\
\hline \multirow{2}{*}{ SECONDARY } & $-0.250 * *$ & -0.026 & $-0.102 *$ & $-0.087^{*}$ \\
\hline & $(0.084)$ & $(0.030)$ & $(0.041)$ & $(0.045)$ \\
\hline \multirow[t]{2}{*}{ HIGH_SCHOOL } & $-0.783 * *$ & $-0.183 * * *$ & $-0.227 * * *$ & $-0.222 * * *$ \\
\hline & $(0.069)$ & $(0.031)$ & $(0.032)$ & $(0.034)$ \\
\hline \multirow[t]{2}{*}{ HSIZE } & $0.043 * * *$ & -0.000 & $0.017 * *$ & $0.012 * *$ \\
\hline & $(0.011)$ & $(0.005)$ & $(0.006)$ & $(0.004)$ \\
\hline \multirow[t]{2}{*}{ TIME } & $-0.132 * * *$ & & & \\
\hline & $(0.711)$ & & & \\
\hline Number of observations & 7,729 & 2,789 & 2,496 & 2,444 \\
\hline Wald chi2(11) & 741.23 & 670.17 & 639.47 & 687.06 \\
\hline Prob > chi2 & 0.000 & 0.000 & 0.000 & 0.000 \\
\hline Pseudo R2 & 0.4200 & 0.4561 & 0.3801 & 0.4291 \\
\hline
\end{tabular}

Note: Coefficients have been transformed to marginal effects, robust standard errors are shown in parentheses beneath the marginal effects; $* \mathrm{p}<0.10, * * \mathrm{p}<0.05, * * * \mathrm{p}<0.01$.

Source: Authors' calculations using LFS 2014-2016 


\subsection{Young LFP rate by location and gender}

The youth living in an urban area may have some differences in comparison with the youth living in a rural area because the level of available jobs, living standard, and education in urban areas. are normally higher.. As a result, the youth LFP rate may be different between them. Moreover, with the gender aspect, there also exists the inequality between men and women. Table 4 shows the probit estimated results for urban and rural areas, males and females to find the difference among them.

The results illustrate that it is consistent with above regression results, however there are some differences among these groups. For example, age had a stronger positive impact on LFP for youth living in urban area than people in rural area (3.26\% points compares to $1.84 \%$ points with statistical significance at $\mathrm{p}<0.01$ ). It can be implied that the labor market in urban was better than that in the rural area, while it provided more jobs opportunities for youth in the urban area. In contrast, age had a smaller positive impact on female group (around $0.66 \%$ points) than that with male. Moreover, female in urban location was less likely to join the labor market than female in the rural areas (at around $0.48 \%$ points).

Table 4. Probit LFP, by location and gender

\begin{tabular}{|c|c|c|c|c|}
\hline & \multicolumn{2}{|c|}{ Living location } & \multicolumn{2}{|c|}{ Gender } \\
\hline & Urban & Rural & Male & Female \\
\hline \multirow{2}{*}{$A G E$} & $0.326^{* * *}$ & $0.184 * * *$ & $0.222 * * *$ & $0.156 * * *$ \\
\hline & $(0.039)$ & $(0.017)$ & $(0.022)$ & $(0.025)$ \\
\hline \multirow[t]{2}{*}{$A G E \_S Q$} & $-0.005 * * *$ & $-0.003 * * *$ & $-0.003 * * *$ & $-0.002 * * *$ \\
\hline & $(0.000)$ & $(0.000)$ & $(0.000)$ & $(0.000)$ \\
\hline \multirow[t]{2}{*}{$R U R A L$} & & & $0.143 * * *$ & $0.131 * * *$ \\
\hline & & & $(0.014)$ & $(0.015)$ \\
\hline \multirow[t]{2}{*}{ FEMALE } & $-0.124 * * *$ & $-0.076^{* * *}$ & & \\
\hline & $(0.019)$ & $(0.011)$ & & \\
\hline \multirow[t]{2}{*}{ MARRIED } & $0.120 * * *$ & $0.123 * * *$ & $0.150 * * *$ & $0.206 * * *$ \\
\hline & $(0.023)$ & $(0.014)$ & $(0.015)$ & $(0.019)$ \\
\hline \multirow{2}{*}{$N O-E D U C$} & $-0.653 * * *$ & $-0.271 * * *$ & $-0.580 * * *$ & $-0.470 * * *$ \\
\hline & $(0.043)$ & $(0.073)$ & $(0.082)$ & $(0.077)$ \\
\hline \multirow{2}{*}{ PRIMARY } & 0.049 & 0.110 & 0.034 & $0.102 * *$ \\
\hline & $(0.083)$ & $(0.017)$ & $(0.040)$ & $(0.039)$ \\
\hline \multirow{2}{*}{ SECONDARY } & -0.004 & -0.014 & $-0.070 *$ & $-0.095 * *$ \\
\hline & $(0.042)$ & $(0.024)$ & $(0.032)$ & $(0.032)$ \\
\hline \multirow{2}{*}{ HIGH_SCHOOL } & $-0.270 * * *$ & $-0.121 * * *$ & $-0.246 * * *$ & $-0.207 * * *$ \\
\hline & $(0.026)$ & $(0.026)$ & $(0.031)$ & $(0.025)$ \\
\hline \multirow[t]{2}{*}{ HSIZE } & 0.020 & 0.004 & $0.007^{*}$ & $0.013 * *$ \\
\hline & $(0.005)$ & $(0.003)$ & $(0.003)$ & $(0.004)$ \\
\hline \multirow[t]{2}{*}{ TIME } & $-0.051 * * *$ & $-0.023 * * *$ & $-0.024 * * *$ & $-0.038 * * *$ \\
\hline & $(0.011)$ & $(0.006)$ & $(0.007)$ & $(0.008)$ \\
\hline Number of observations & 3,262 & 4,467 & 3,810 & 3,919 \\
\hline Wald chi2(11) & 1061.29 & 1040.53 & 909.94 & 1098.76 \\
\hline Prob > chi2 & 0.000 & 0.000 & 0.000 & 0.000 \\
\hline Pseudo R2 & 0.4917 & 0.3524 & 0.4498 & 0.4034 \\
\hline
\end{tabular}

Note: Coefficients have been transformed to marginal effects, robust standard errors are shown in parentheses beneath the marginal effects; $* \mathrm{p}<0.10, * * \mathrm{p}<0.05$, *** $\mathrm{p}<0.01$.

Source: Authors' calculations using LFS 2014-2016

\subsection{Young LFP rate by ages}

Among ages of the youth, some different features can impact the youth decision in labour force join. Specifically, for ages of 16 to 18, most of young people are studying at high schools, 
meanwhile people of ages ranged from 19 to 24 study at college or university and ages from 25 to 30 almost have completed their study. According to these results, we divided the youth into three subgroups (group 1, aged from 16-18; group 2, aged 19-24; and group 3, aged from 25-30) to run the probit estimation.

Table 5 shows the final regression results for three aged groups, and it indicates that there were different impacts of independent variables on the rate of youth LFP in Thai Nguyen province, Vietnam. For example, the age variable had a higher negative impact on LFP for the first two younger groups while it had no impact on LFP for the oldest group. It means that most of younger people in aged from 16 to 24 belonged to school age while people in aged between 25 and 30 almost graduated and could go to work. Female variable had a negative impact on LFP for the last two oldest group (at around $1.97 \%$ points and $0.35 \%$ points for each group respectively), but it had no effect on LFP for the youngest group since female in the youngest group were still studying at high school level in Vietnam.

Table 5. Probit LFP rate by aged groups

\begin{tabular}{|c|c|c|c|}
\hline & $\begin{array}{c}\text { Aged group } \\
(16-18)\end{array}$ & $\begin{array}{c}\text { Aged group } \\
(19-24)\end{array}$ & $\begin{array}{c}\text { Aged group } \\
(25-30)\end{array}$ \\
\hline \multirow[t]{2}{*}{$A G E$} & $-2.804 * *$ & $-0.294 *$ & -0.077 \\
\hline & $(0.952)$ & $(0.168)$ & $(0.066)$ \\
\hline \multirow[t]{2}{*}{$A G E \_S Q$} & $0.085 * *$ & $0.008 * *$ & 0.001 \\
\hline & $(0.028)$ & $(0.003)$ & $(0.001)$ \\
\hline \multirow{2}{*}{$R U R A L$} & $0.223 * * *$ & $0.202 * * *$ & 0.004 \\
\hline & $(0.022)$ & $(0.019)$ & $(0.006)$ \\
\hline \multirow{2}{*}{ FEMALE } & 0.003 & $-0.197 * * *$ & $-0.035 * * *$ \\
\hline & $(0.025)$ & $(0.019)$ & $(0.006)$ \\
\hline \multirow[t]{2}{*}{ MARRIED } & $0.405 * * *$ & $0.241 * * *$ & $0.039 * * *$ \\
\hline & $(0.093)$ & $(0.019)$ & $(0.010)$ \\
\hline \multirow[t]{2}{*}{ NO-EDUC } & $-0.202 * *$ & $-0.596 * * *$ & $-0.181 * * *$ \\
\hline & $(0.065)$ & $(0.065)$ & $(0.052)$ \\
\hline \multirow[t]{2}{*}{ PRIMARY } & $0.183 * *$ & 0.093 & 0.021 \\
\hline & $(0.192)$ & $(0.066)$ & $(0.009)$ \\
\hline \multirow[t]{2}{*}{ SECONDARY } & -0.150 & -0.003 & 0.002 \\
\hline & $(0.192)$ & $(0.044)$ & $(0.009)$ \\
\hline \multirow[t]{2}{*}{ HIGH_SCHOOL } & -0.115 & $-0.357 * * *$ & $-0.027 * *$ \\
\hline & $(0.144)$ & $(0.027)$ & $(0.009)$ \\
\hline \multirow[t]{2}{*}{ HSIZE } & $0.003 * * *$ & $0.017 * * *$ & 0.000 \\
\hline & $(0.008)$ & $(0.005)$ & $(0.001)$ \\
\hline \multirow[t]{2}{*}{ TIME } & $-0.057 * * *$ & $-0.026 * *$ & $-0.010 * *$ \\
\hline & $(0.014)$ & $(0.011)$ & $(0.003)$ \\
\hline Number of observations & 1,305 & 2,933 & 3,491 \\
\hline Wald chi2(11) & 209.47 & 737.77 & 105.98 \\
\hline Prob > chi2 & 0.000 & 0.000 & 0.000 \\
\hline Pseudo R2 & 0.1474 & 0.3401 & 0.0759 \\
\hline
\end{tabular}

Note: Coefficients have been transformed to marginal effects, robust standard errors are shown in parentheses beneath the marginal effects; $* \mathrm{p}<0.10, * * \mathrm{p}<0.05, * * * \mathrm{p}<0.01$.

Source: Authors' calculations using LFS 2014-2016

\section{Conclusion}

In the national progress, human capital accumulation in general and the young labour force in particular plays a crucial role. In this paper, we employed the data from LFS in the years of 2014, 
2015 and 2016. By using the probit estimated setup, we identified the factors that affected the young LFP in Thai Nguyen province, Vietnam.

The findings indicate that many factors were influencing the youth choice to enter the labour force with a high statistically significant level, including individual characteristics (age, gender, living location, educational level) and household demographic feature (household size). Interestingly, married youth were more likely to join the labour market than those in counterpart group. In term of education level group, youth with no education level had a lower probability to participate the labour market in comparison with those in counterpart group. Moreover, the results show that there existed the difference between gender groups and living areas; young females were less likely to participate in the labour market than young males (at $0.66 \%$ points). It can be explained that young females belong to maternity status. Young people living in rural areas had higher probability to join the labour force compared to those living in urban areas (around $1.42 \%$ points). The LFP rate has had a downward trend over years. The youth having a higher education level were more likely to delay their decision to participate in the labour force than those of their counterpart group. This may explain that they need to spend their time at the school studying. Moreover, there also existed the different impacts among different age groups.

Our findings may shed some lights on the Government in labour management or policy design in the future to meet the demand of the young labour force. Based on our analysis in this paper, we can provide to the policy-maker some recommendations; for instance, the government can design policies to promote knowledge and skills for young labours to suit with labor market requirements today. In particular, we may have to focus on female labours, since they belong to the vulnerable groups in the society.

\section{REFERENCES}

[1] C. V. Nguyen and N. M. Pham, "Economic growth, inequality, and poverty in Vietnam," Asian-Pacific Economic Literature, vol. 32, no. 1, pp. 45-58, 2018.

[2] G. T. Long and L. T. Ly, "Determinants of LFP of older people in Vietnam," Journal of Economics and Development, vol. 17, no. 2, pp. 28-52, 2015.

[3] M. Kreibaum and S. Klasen, "Missing men: differential effects of war and socialism on female LFP in Vietnam," Discussion Papers, No. 181, Courant Research Centre PEG, 2015.

[4] S. Mendolia, N. Nguyen, and O. Yerokhin, "The impact of parental illness on children's schooling and LFP: evidence from Vietnam," Review of Economics of the Household, vol. 17, no. 2, pp. 469-492, 2019.

[5] T. Q. Tran, A. L. Tran, T. M. Pham, and H. V. Vu, "Local governance and occupational choice among young people: First evidence from Vietnam," Children and Youth Services Review, vol. 86, pp. 21-31, 2018.

[6] T. T. Tran, "Youth transition to employment in Vietnam: A vulnerable path," Journal of Education and Work, vol. 31, no.1, pp. 59-71, 2018.

[7] Y. Liu, C. B. Barrett, T. Pham, and W. Violette, "The intertemporal evolution of agriculture and labor over a rapid structural transformation: Lessons from Vietnam," Food Policy, vol. 94, 2020, Art. no. 101913.

[8] S. Klasen, T. T. N. Le, J. Pieters, and M. S. Silva, "What drives female LFP? Comparable micro-level evidence from eight developing and emerging economies," The Journal of Development Studies, vol. 57, no. 3, pp. 417-442, 2021.

[9] General Statistics Office, Vietnam Statistical Yearbook 2019. Statistical Publishing House, Hanoi, 2019.

[10] The XI National Assembly of the Socialist Republic of Vietnam, Law No. 53/2005/QH11: Youth Law. Hanoi, November 29, 2005.

[11] S. Xu, Z. Zhang, and Y. Guo, "A Discussion on the Labor Participation Rate of Middle- and Old-age Males in Taiwan in the Implementation of National Health Insurance," Economics and Management Essays, vol. 7, no. 2, pp. 199 - 226, 2011. 